\title{
Circular Earthwork Krek 52/62: \\ Recent Research on the Prehistory of Cambodia
}

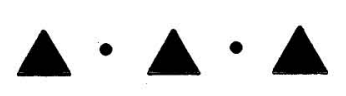

\author{
GERD ALBRECHT, MIRIAM NOËL HAIDLE, CHHOR SIVLENG, \\ HEANG LEANG HONG, HENG SOPHADY, HENG THAN, \\ MAO SOMEAPHYVATH, SIRIK KADA, SOM SOPHAL, \\ THUY CHANTHOURN, AND VIN LAYCHOUR
}

FOR MORE THAN IOO YEARS, studies on prehistory have been neglected in archaeological research on Cambodia, which is dominated by the wealth and beauty of Angkorian remains. Most prehistoric sites (Fig. 1) were found by chance in the course of ploughing fields or laying out plantations; only a few have been studied systematically (Carbonnel 1970, 1979; Groslier 1966a, 1966b; Levy 1943; Malleret 1959; Mansuy 1902, 1923; Mourer and Mourer 1970; Noulet 1879; Pavie 1904; Saurin 1969).

Due to political turbulence during the second half of this century, the knowledge about Cambodian prehistory still remains at an initial level (Mourer 1977, 1994; Mourer and Mourer 1971). Even a coarse field survey to register the country's prehistoric sites is lacking as is more detailed information on typology, technology, subsistence, and the relationship of different cultural levels to adjacent regions. Only a few sites have been excavated; dating, especially radiocarbon dates, is rare (Carbonnel and Delibrias 1968). Publications on fieldwork are in most cases sketchy and limited to the rough description of the site and some selected artifacts.

This is a very slender base for Cambodian prehistory today: it has to be broadened by collecting more data to draw a picture of the life of prehistoric populations. The intention of this paper is to add new evidence on circular earthworks in the Kompong Cham province and the adjacent region in Vietnam. After a brief review of the research on this particular site group, the results of the actual fieldwork at Krek 52/62 will be presented together with some observations made at other circular earthwork sites. The new data allow a critical discussion on the structural and functional use of these earthen structures.

Dr. Albrecht and Dr. Haidle are Lecturers at the University of Tübingen, Germany and the Royal University of Fine Arts, Phnom Penh. Chhor Sivleng, Heang Leang Hong, Heng Sophady, Heng Than, Mao Someaphyvath, Sirik Kada, Som Sophal, Thuy Chanthourn, and Vin Laychour are graduates of the Faculty of Archaeology, Royal University of Fine Arts, Phnom Penh, Cambodia.

Asian Perspectives, Vol. 39, No. 1-2, (C) 2001 by University of Hawai'i Press. 


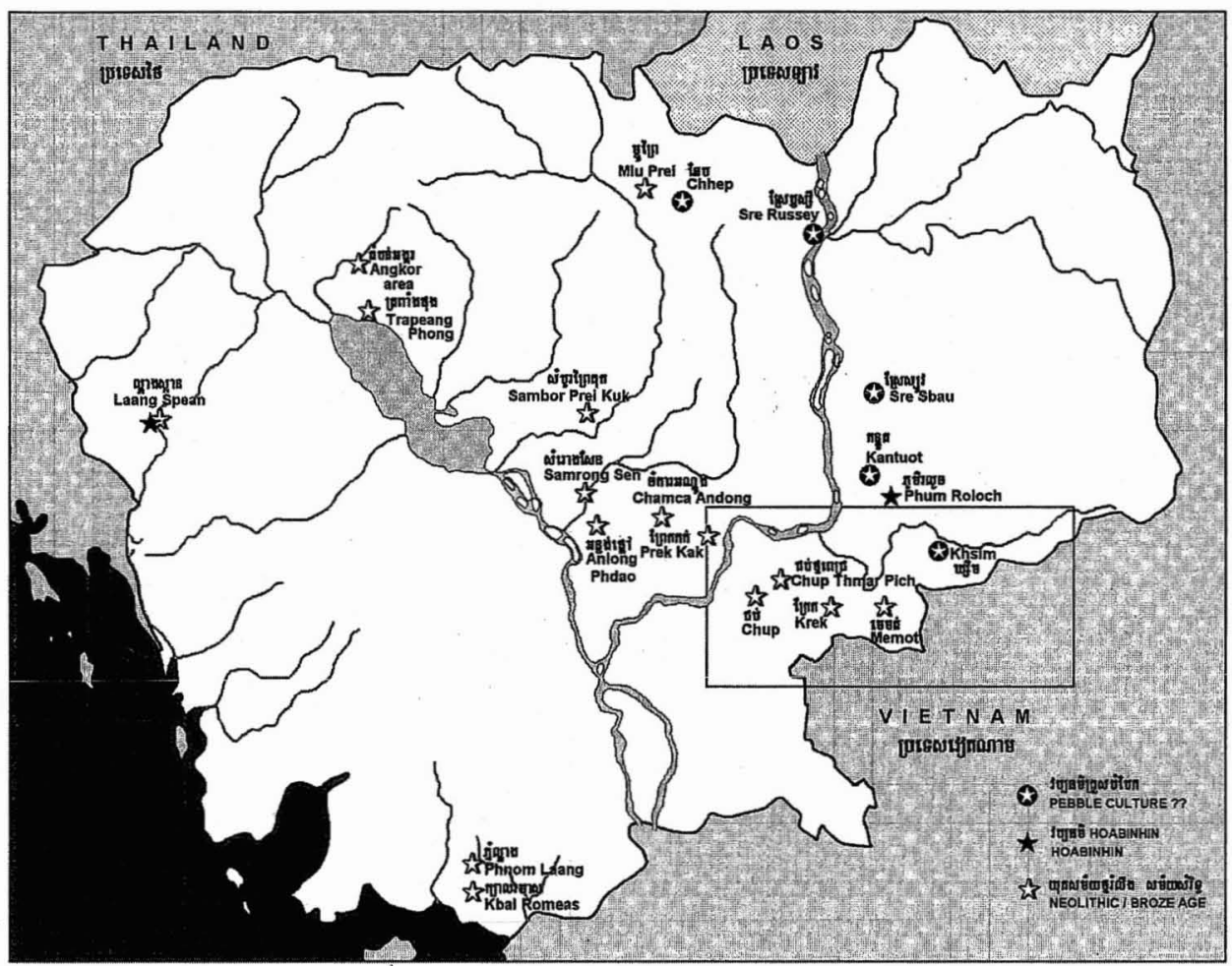

Fig. 1. Cambodian prehistoric sites.

\section{RESEARCH HISTORY}

In 1959, Louis Malleret described the circular earthworks with outer walls and inner ditches as a new category of prehistoric site in Cambodia. He listed 17 earthworks of this type in the red soil region east of the Mekong in the Kompong Cham province and adjacent Vietnam (Fig. 2). Except for one, all sites were restricted to the areas of rubber plantations, stretching from the Ponhea Krek district, $60 \mathrm{~km}$ southeast of Kompong Cham, to the Song Bé Basin, $100 \mathrm{~km}$ north of Ho Chi Minh City.

Malleret did not excavate any of these sites. He dated them as Neolithic based on a few surface finds and interpreted them as fortifications with palisades on the tops of the walls. In 1962, Bernard Philippe Groslier excavated a circular earthwork near Memot. In the very short reports on his fieldwork (Groslier 1966a, 1966b) he mentioned several different cultural layers at the site within deposits more than $3 \mathrm{~m}$ in thickness. On the basis of his findings, Groslier defined a new, as he believed, Neolithic cultural complex, the Memotien. He neither gave the exact location of the site (see below), nor did he publish his results in detail. Research on these earthwork sites in the red soil region resumed only in 1996, with an examination of the Krek 52/62 earthworks (No. 15 after the classification of Malleret) by Yasushi Kojo and students of the Royal University of Fine Arts, Phnom Penh (RUFA) (Kojo and Pheng 1998). A coarse survey of the site and 


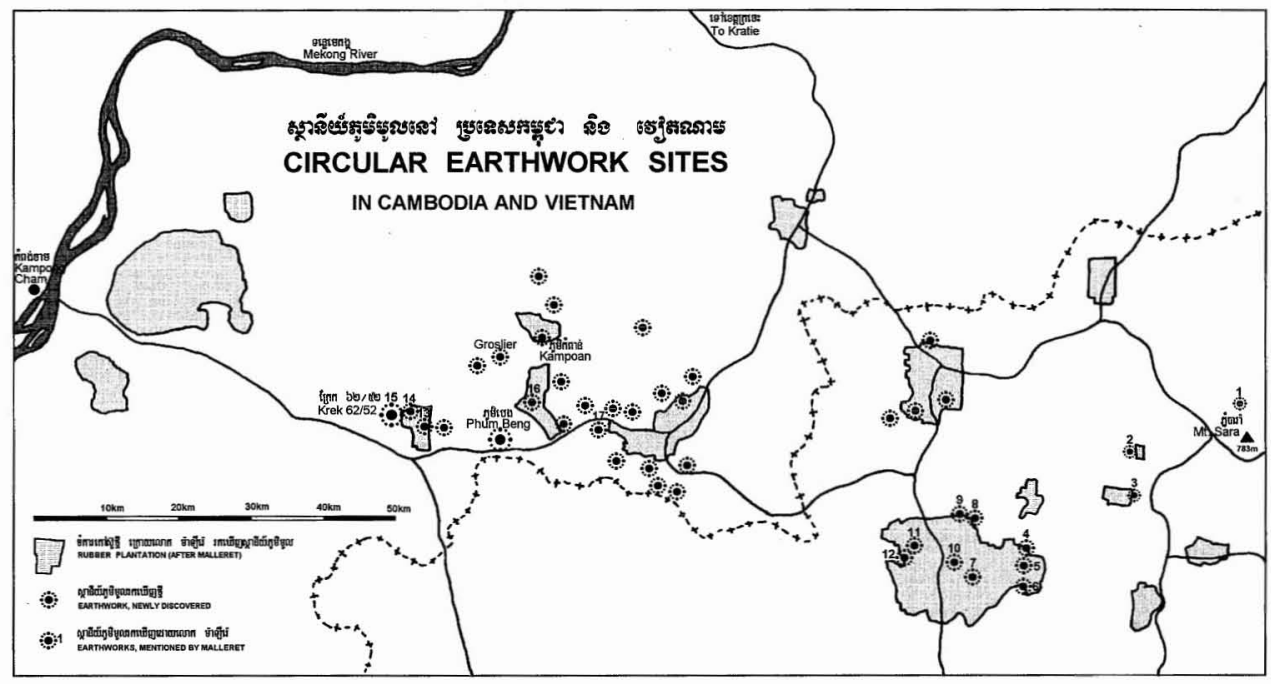

Fig. 2. Circular earthworks in Cambodia and Vietnam. Included are the sites of Malleret (1959), newly discovered sites mentioned in the text, as well as recent discoveries by the Memot Centre of Archaeology (Thuy Chanthourn and Heng Sophady pers. comm.), Michael Dega (pers. comm.), and Ngyen Trung Do (1999).

ten drill soundings with a hand auger were done which led to the postulation of two different occupational layers. The site was again interpreted as a Neolithic defensive structure (Nop et al. 1996).

Also in 1996, Kojo and Pheng noted a yet undocumented circular earthwork by examining aerial photographs. The site is situated about $5 \mathrm{~km}$ southwest of Memot within the Chalang rubber plantation. Having an outer wall and an inner trench, it clearly belongs to the typical earthworks of the red soil region (Kojo and Pheng 1997). The structure was dated to the Neolithic period on the basis of surface finds.

In the same year a team from the University of Hawai'i carried out a survey on circular earthworks in the Krek and Memot districts (Dega et al. 1997). The work continued in the following years, concentrating on the investigation of several areas in Chi Peang and five other earthwork sites.

More intensive fieldwork started at the end of 1996 at Krek 52/62 and continued through 2001. Surveys and soundings of other sites in the Krek and Memot districts were also undertaken (Albrecht and Haidle 1999). Within the framework of a long-term training program in field archaeology at the Royal University of Fine Arts, Phnom Penh, conducted by the German Academic Exchange Service, nine weeks were spent at the site studying site catchment, surveying, mapping, and excavating. During the 1998 to 2000 campaigns, 15 other circular earthworks not previously documented were discovered by our group between Krek and Memot. Asking people in the countryside and in the rubber plantations on a one-day site catchment trip in 1998, for instance, yielded three more sites. Additionally, the circular earthwork excavated by Groslier was rediscovered on 1 March 1999 (Table 1). Figure 2 shows Malleret's (1959) sites as well as the newly discovered 
Table i. List of Newly Documented Circular Earthwork Sites in Krek and Memot Districts, Kompong Cham Province

\begin{tabular}{|c|c|c|c|c|}
\hline NAME & CO-ORDINATES & $\begin{array}{c}\text { METERS } \\
\text { ABOVE } \\
\text { SEA LEVEL }\end{array}$ & $\begin{array}{l}\text { DATE OF } \\
\text { DISCOVERY }\end{array}$ & DISCOVERED BY \\
\hline $\begin{array}{l}\text { Phoum Beng } \\
\text { (Memot district) }\end{array}$ & $\begin{array}{l}\text { N } 11^{\circ} 47.367^{\prime} \\
\text { E } 106^{\circ} 03.817^{\prime}\end{array}$ & 102 & 05.02 .1998 & Albrecht, G., Dega, Peng, Sirik \\
\hline $\begin{array}{l}\text { Phoum Chong } \\
\text { (Memot district) }\end{array}$ & $\begin{array}{l}\text { N } 11^{\circ} 54.015^{\prime} \\
\text { E } 106^{\circ} 02.433^{\prime}\end{array}$ & 185 & 05.02 .1998 & Albrecht, G., Dega, Peng, Sirik \\
\hline $\begin{array}{l}\text { Phoum Kampoan } \\
\text { (Memot district) }\end{array}$ & $\begin{array}{l}\text { N } 11^{\circ} 55.300^{\prime} \\
\text { E } 106^{\circ} 05.483^{\prime}\end{array}$ & 140 & 05.02 .1998 & Albrecht, G., Dega, Peng, Sirik \\
\hline $\begin{array}{l}\text { Chamkar Thmey } \\
\text { (Memot district) }\end{array}$ & $\begin{array}{l}\text { N } 11^{\circ} 53.845^{\prime} \\
\text { E } 106^{\circ} 04.750^{\prime}\end{array}$ & 160 & 28.02 .1999 & Heang, Thuy \\
\hline $\begin{array}{l}\text { Huon Khim } \\
\text { (Memot district) }\end{array}$ & $\begin{array}{l}\text { N } 11^{\circ} 56.905^{\prime} \\
\text { E } 106^{\circ} 06.805^{\prime}\end{array}$ & 125 & 01.03 .1999 & $\begin{array}{l}\text { Albrecht, G. and B., Haidle, } \\
\text { Heang, Thuy, Urban }\end{array}$ \\
\hline $\begin{array}{l}\text { Groslier } \\
\text { (Memot district) }\end{array}$ & $\begin{array}{l}\text { N } 11^{\circ} 54.545^{\prime} \\
\text { E } 106^{\circ} 03.612^{\prime}\end{array}$ & 180 & 01.03.1999 & $\begin{array}{l}\text { Albrecht, G. and B., Haidle, } \\
\text { Heang, Thuy, Urban }\end{array}$ \\
\hline $\begin{array}{l}\text { Chhok Khley } \\
\text { (Memot district) }\end{array}$ & $\begin{array}{l}\text { N } 11^{\circ} 58.580^{\prime} \\
\text { E } 106^{\circ} 04.775^{\prime}\end{array}$ & 130 & 03.03.1999 & Albrecht, G., Heang, Thuy \\
\hline
\end{tabular}

sites mentioned below. Added are the very recent discoveries by the Memot Centre of Archaeology (Thuy Chanthourn and Heng Sophady, pers. comm.), Michael Dega (pers. comm.), and Ngyen Trung Do (1999).

\section{THE NEWLY DOCUMENTED EARTHWORKS OF I998 AND I999}

The distribution of the circular structures is limited to the red soil region in southeast Cambodia and southern Vietnam. Like Krek 52/62, most of the circular earthworks mentioned by Malleret (1959) have been recognized in rubber plantations with the help of general inspectors of the plantations or by aerial photographs. However, the use of aerial photographs is restricted to recently cleared areas or young plantations; within older forests the structures are hidden by the trees. Certainly, there are numerous earthworks that have not as yet been documented. The newly noted earthworks have been known to the local people for a long time, and in this sense the structures are not newly discovered. The following list of circular earthworks can be presented only because of the knowledge of local peasants and workers.

PHOUM BENG- $11^{\circ} 47.367^{\prime} \mathrm{N}, 106^{\circ} 03.817^{\prime} \mathrm{E}$. The outer diameter is c. $230 \mathrm{~m}$. This earthwork is situated close to the Krek-Memot road on a flat hilltop slightly sloping to the east and overlooking the surrounding area. Mapping of the site showed an outer rampart with a flat outer and steep inner embankment and a wide, shallow inner ditch (see Fig. 6). At the edge of the inner plateau the elevation forms a nearly complete circular ring. The highest point is opposite the entrance and faces east towards the nearest creek, which is $2 \mathrm{~km}$ away. Typically, the inner platform is lower than the surrounding natural surface. A preliminary 
investigation and three small test pits on different portions of the site allow some conclusions. In one test pit two concentrations of cultural material in different levels suggest the existence of two settlements or habitation layers and can hardly be explained by natural secondary movements after the time of the occupation(s). However, this evidence is not supported by the single occupational layer in another test trench.

PHOUM CHONG- $11^{\circ} 54.015^{\prime} \mathrm{N}, 106^{\circ} 02.433^{\prime} \mathrm{E}$. The site is situated on a spur at the edge of a plateau, surrounded to the east, south, and west by a deep valley system with nearby access to water. Similar to the other sites of this group, Phoum Chong consists of an outer wall and an inner ditch. A simple entrance is located in the northwestern part of the structure while in the southeast a more complex entrance with a tongue-shaped extension of the inner platform was built. In the northern part of the structure the height of the wall is below average. In the southern part, towards the valley, the wall is in some parts markedly higher, resembling a sort of tower on both sides of the southwestern entrance. To the south, next to the entrance, part of the wall is missing. The inner plateau seems not to be lower than the surrounding area, but this impression might be deceiving as the structure is situated on a slight slope to the north, which declines sharply to the south.

PHOUM KAMPOAN- $11^{\circ} 55.300^{\prime} \mathrm{N}, 106^{\circ} 05.483^{\prime} \mathrm{E}$. The outer diameter is 250 to $270 \mathrm{~m}$. Again situated at the edge of a plateau, this site shows the common structure of an outer rampart and an inner shallow ditch (see Fig. 6). Perhaps due to the steep slope towards a valley in the north where water is accessible $800 \mathrm{~m}$ distant, the outer wall is interrupted in the north-northeast. The main entrance faces south and is characterized by a semicircular flat wall extending to the outside, only interrupted in the middle, together with a semicircular extension of the ditch. The inner platform shows a tongue-shaped extension towards the entrance. This site gave us the first hint of a more complicated entrance, as we would observe later in the Groslier and Huon Khim sites and also in some circular earthwork sites in Vietnam (Loc Ninh and Phu Mieng or Malleret No. 8). The settlement remains form a high inner circle around the inner plateau, in some parts even higher than the outer wall. Phoum Kampoan is extremely rich in surface finds, mainly stone artifacts; potsherds are rare. In the backdirt of a trench recently dug (by villagers?) a nearly 4-cm-long cylindrical bead probably made of resin was found. A test pit showed a thick but undivided single occupation layer, full of stone artifacts, interestingly made of two different basaltic raw materials.

CHAMKAR THMEY $-11^{\circ} 53.845^{\prime} \mathrm{N}, 106^{\circ} 04.750^{\prime} \mathrm{E}$. This circular earthwork is situated in the Chhlong rubber plantation behind Chamkar Thmey village, more than $3 \mathrm{~km}$ southwest of the Kampoan site. Typically, the features of this earthwork are a slight slope from the outside to the top of the outer wall and a steep descent to the ditch, followed by an inner platform deeper than the surrounding natural surface. The elevated zone at the edge of the platform can be clearly observed, but is not very distinctive. Southwest of this habitation zone (see below), the surface finds are concentrated. The single entrance is situated in the northwest, in the direction of the nearby slope towards the Prek Chhlong Valley; 
nowadays, running water from the creek is only accessible at a distance of $700 \mathrm{~m}$. This site could be Malleret No. 16, but the information given by Malleret (1959: 418 ) is not clear.

HUON кнIм $-11^{\circ} 56.905^{\prime} \mathrm{N}, 106^{\circ} 06.805^{\prime} \mathrm{E}$. The outer diameter is c. $200 \mathrm{~m}$. The site is located approximately $2 \mathrm{~km}$ north of Kampoan Village and about $3 \mathrm{~km}$ northeast of the Kampoan site. The entrance, situated in the northwest and directed to a ravine with access to water within 500 to $700 \mathrm{~m}$, has a similar, but even more complicated structure than the Kampoan site. Again the outer wall has a semicircular extension to the outside, but the inner platform shows no tongueshaped outgrowth. Instead of this, a small mound appears in the middle of the wide extension of the ditch, which might be interpreted as a kind of a bridge pier for a wooden construction.

The surface of the site is extremely rich in stone tools, perhaps as a result of recent planting. Potsherds are very rare. Most of the hundreds of adzes are only flaked; polishing is the exception. Remarkable is the number of blades, usually rare in circular sites, which certainly are not debris of the adze production. The main pyroxene-hornfells metamorphic raw material of the Huon Khim site differs from all other sites known so far and is less weathered. Only at the Kampoan site was similar raw material observed in small quantities.

GROSLIER SITE- $11^{\circ} 54.545^{\prime} \mathrm{N}, 106^{\circ} 03.612^{\prime} \mathrm{E}$. The outer diameter is c. $220 \mathrm{~m}$. The site is located near Phoum Chhlong 3, approximately $1 \mathrm{~km}$ to the east of the village and at the eastern end of a rubber plantation, grid number 25 . It lies at the edge of a plateau close to a steep valley. The stream source is $300 \mathrm{~m}$ northeast of the site, and passes the site to the north, giving easy access to water less than $200 \mathrm{~m}$ away. The entrance in the north is the same shape as the Kampoan site with a semicircular extension of the outer wall (see Fig. 6) and a tongue-shaped outgrowth of the inner platform. One test trench measuring $1 \mathrm{~m}^{2}$ was excavated on 2 March 1999 at the edge of the inner plateau towards the ditch in the northern part of the site: only one clearly defined occupational layer of around $90 \mathrm{~cm}$ could be observed. There were no traces of the fourteen layers and over $3 \mathrm{~m}$ of deposits (in the wall area?) recorded by Groslier (1966a:195; see above).

The few recently excavated decorated potsherds show clear similarities with the assemblage of Groslier's excavation still preserved at the National Museum Phnom Penh. However, the proportions of decorated to undecorated fragments are completely different in the two assemblages: two-thirds of the potsherds from the collection at the National Museum are decorated, apparently due to Groslier's selection. Most of the undecorated pieces of the old excavation were not kept. The variety of decorative motifs in the Groslier collection (Figs. 3, 4) has never been found in an equivalent amount in other circular earthworks, such as Krek $52 / 62$. Noteworthy are the geometrical decorations on inverted, wide, and flattened rims (Fig. 3:14, 17, 20; Fig. 4:1, 2, 15).

CHHOK KHLEY $-11^{\circ} 58.580^{\prime} \mathrm{N}, 106^{\circ} 04.775^{\prime} \mathrm{E}$. The outer diameter is c. $220 \mathrm{~m}$. The site is located about $3 \mathrm{~km}$ northeast of Phoum Lo Village towards Phoum Tektom at the northernmost edge of the same plateau as the Huon Khim site, which lies $3.5 \mathrm{~km}$ to the southeast. Two entrances in the southeast and northwest 

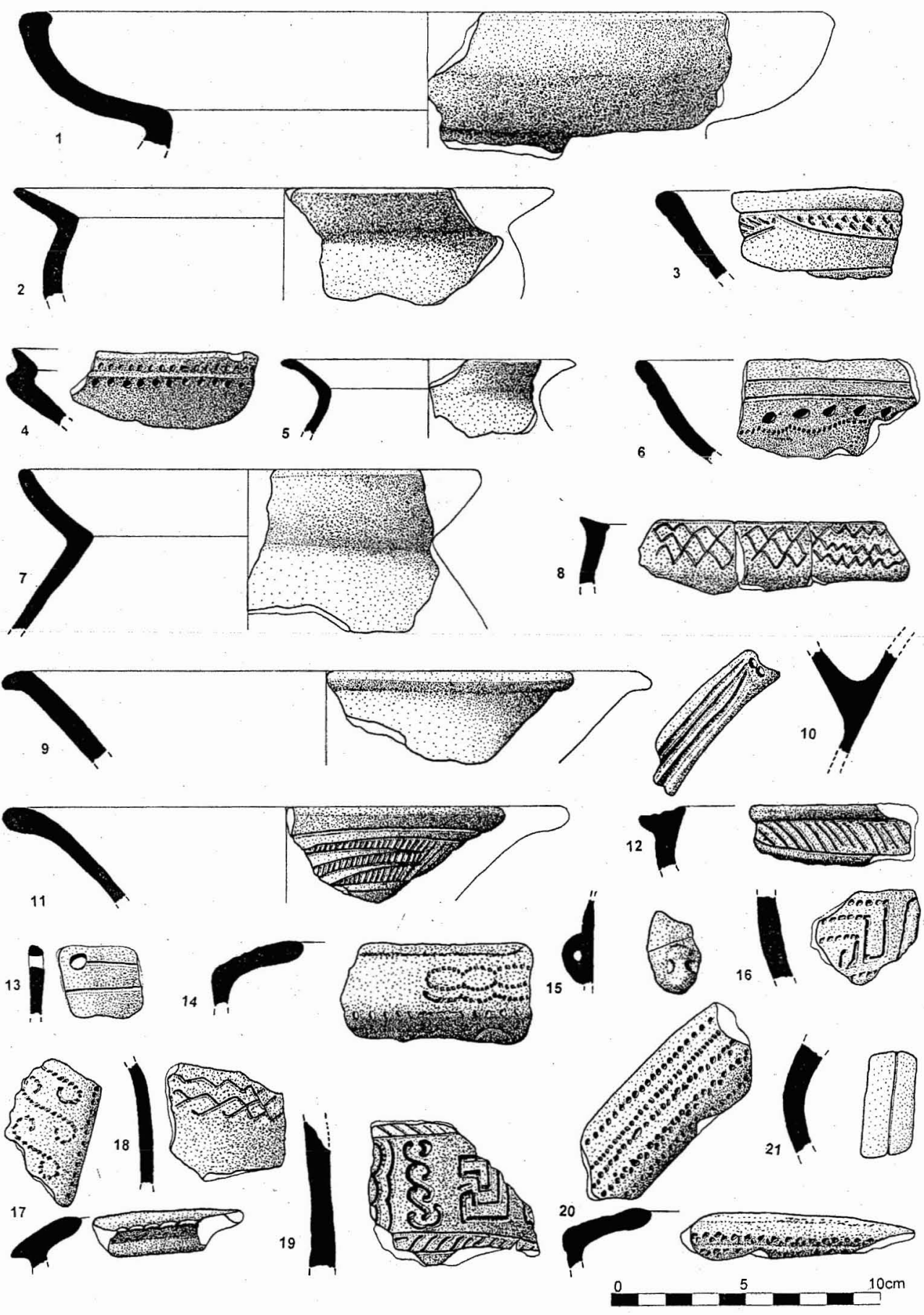

Fig. 3. 1-21: examples of pottery form and decoration types from the Groslier site. Collection of B. P. Groslier, National Museum, Phnom Penh. 

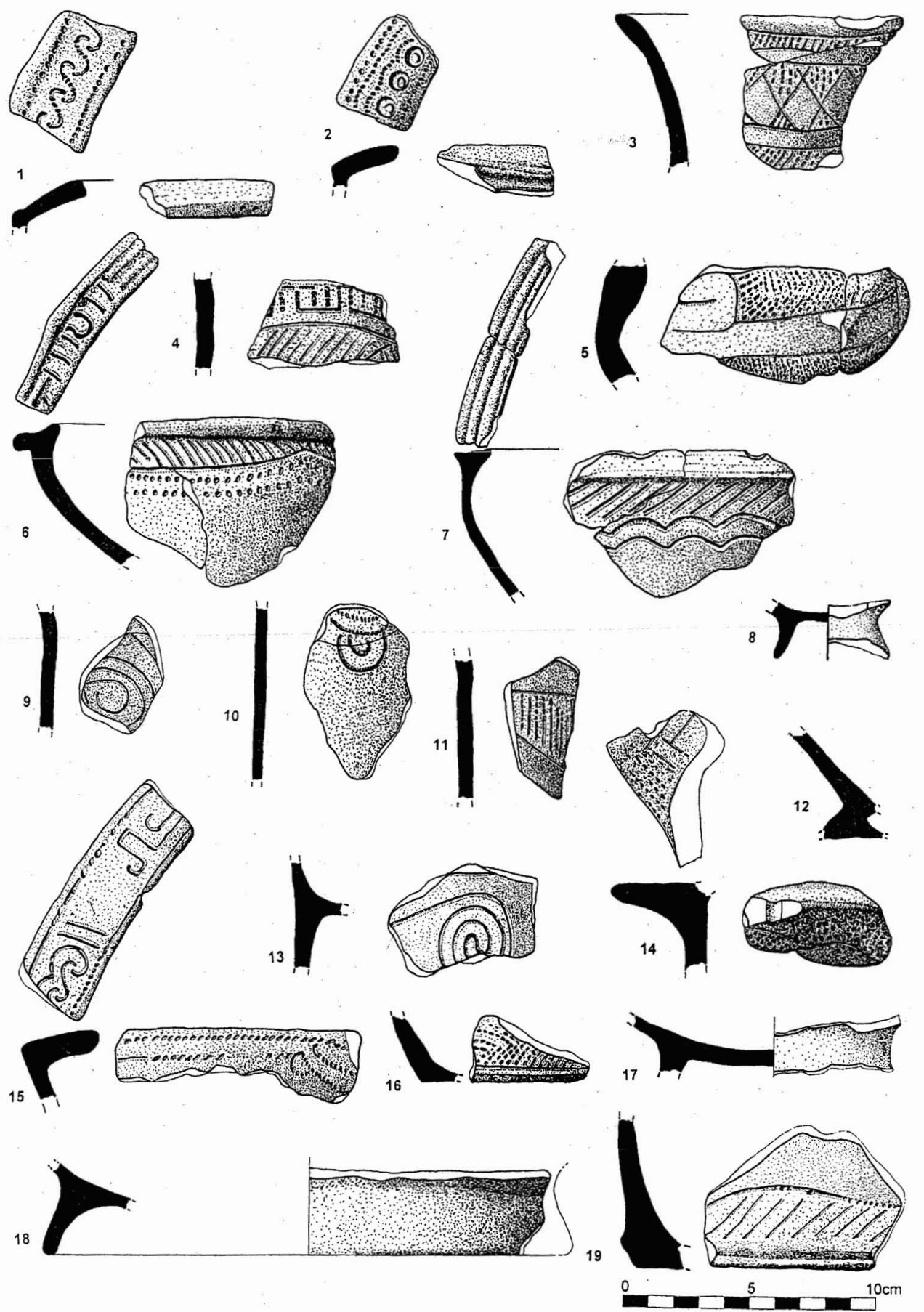

Fig. 4. 1-19: examples of pottery form and decoration types from the Groslier site. Collection of B. P. Groslier, National Museum, Phnom Penh. 
are facing each other; the closest water supply is approximately $0.5 \mathrm{~km}$ to the southeast. The complex structure in the southeast is constructed in the same way as the Huon Khim site. The other one is still heavily overgrown by bamboo forest. Only some areas of the site have recently been cleared and nonpermanently settled by villagers from Phoum Lo. In these areas, very few surface finds could be observed.

\section{THE KREK $52 / 62$ SITE}

Krek 52/62, which is identical to Malleret No. 15, was named according to its location within the grid system of the Krek rubber plantation between grids 52 and 62. As is typical for this site type, Krek 52/62 is located on a slight slope (Fig. 5). The largest outer diameter of the structure is around $255 \mathrm{~m}$; it consists of an outer bank and an inner trench. The ditch is up to $25 \mathrm{~m}$ wide and encloses an inner plateau with an average diameter of around $150 \mathrm{~m}$.

A cross section offers more detailed information about the situation (Fig. 6). The natural surface slopes down $1.5 \mathrm{~m}$ over a distance of about $250 \mathrm{~m}$ from northwest to southeast. The wall rises only slightly on the outside, up to $2 \mathrm{~m}$ above natural soil level. The inner side of the earth rampart falls steeply to the

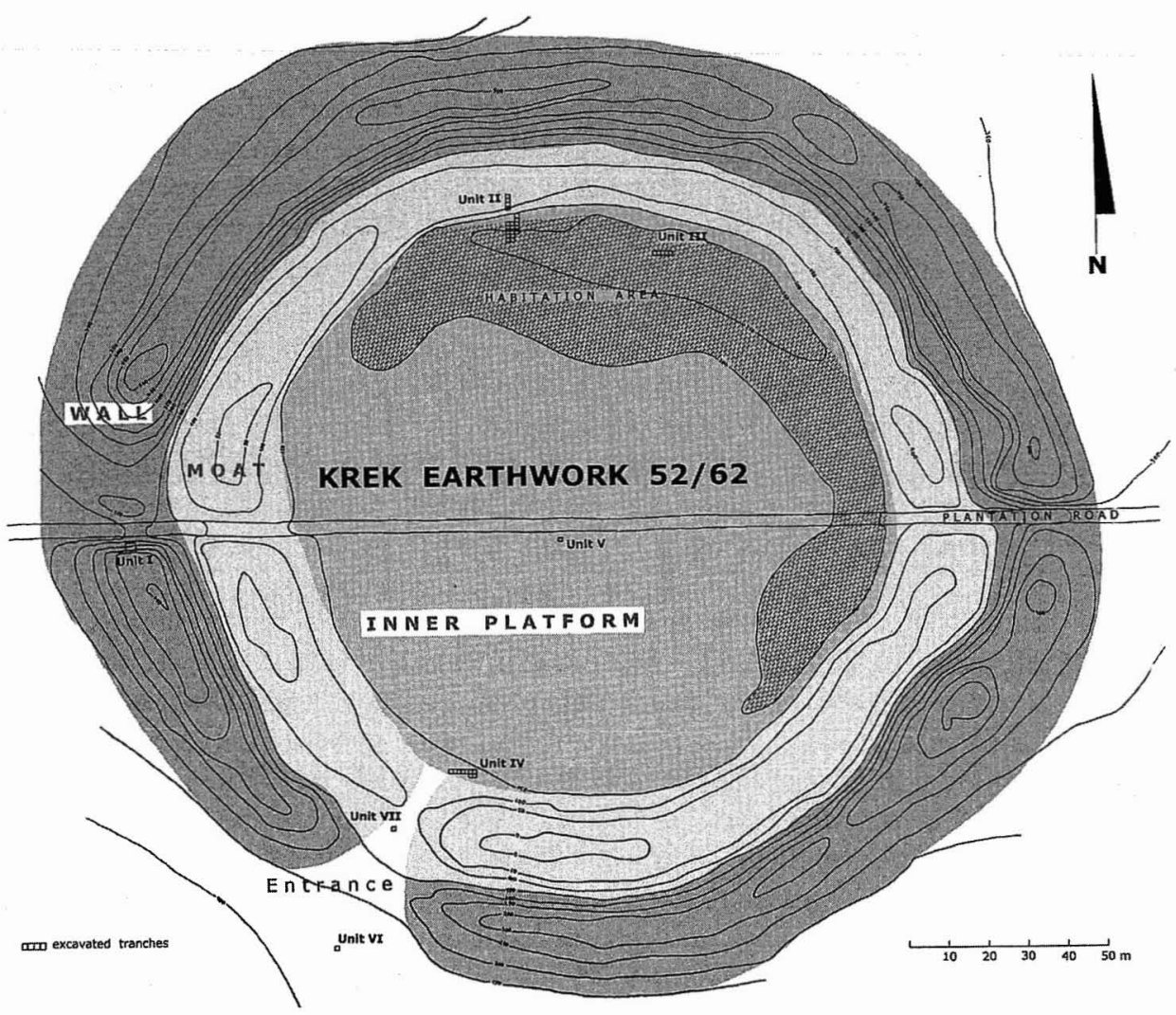

Fig. 5. Krek 52/62. 

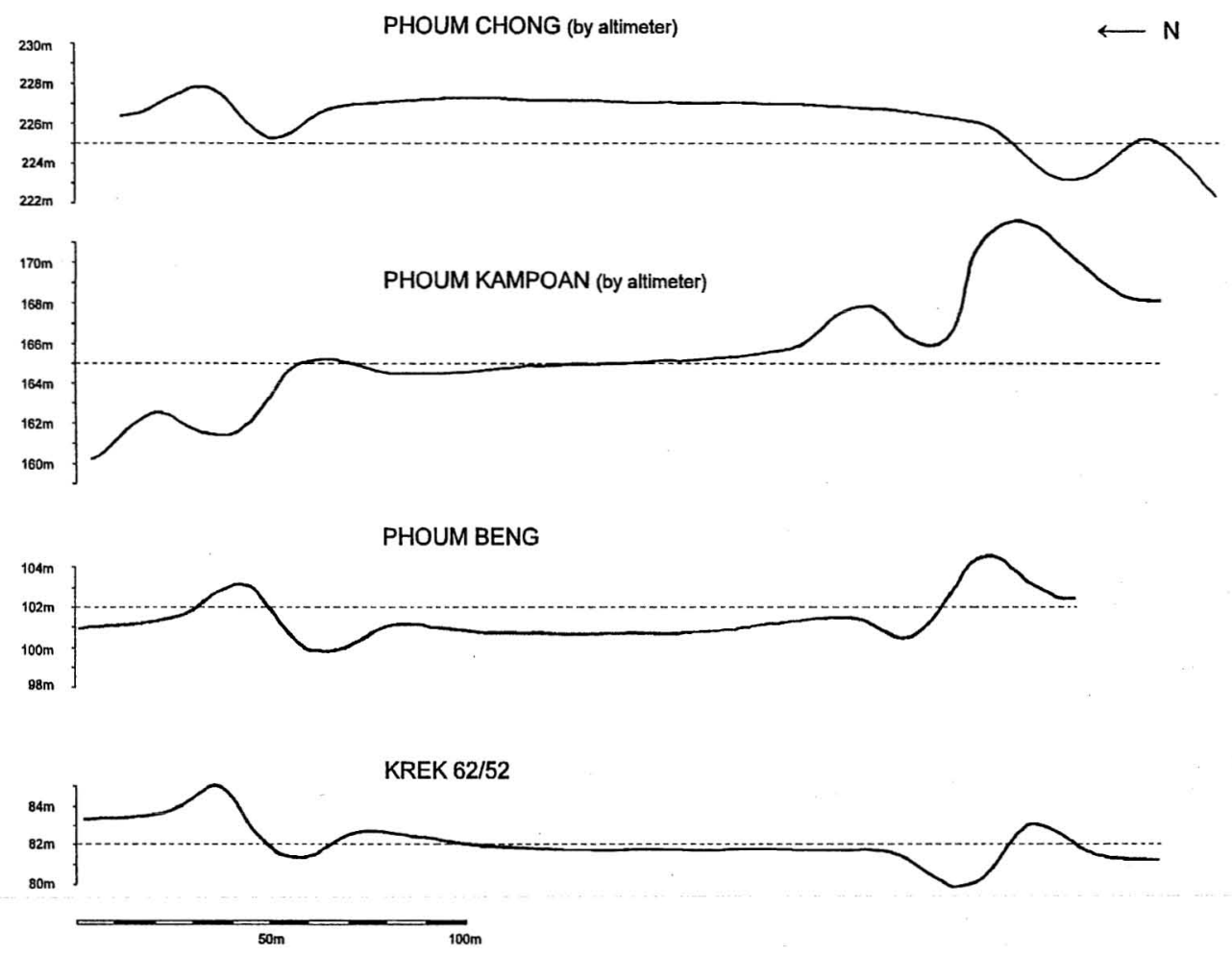

Fig. 6. Profiles of circular earthworks in Cambodia.

adjacent ditch. Here, the difference in height is up to $4 \mathrm{~m}$. The ditch is wide and shallow, the inner plateau is at maximum only $1.5 \mathrm{~m}$ higher. To create this leveled inner plateau, soil has been removed in some parts to a depth of around $1 \mathrm{~m}$ below the natural surface.

At the edge of the plateau some areas in the northeastern half of the structure are elevated, but according to the results of our excavation, this zone can no longer be taken as an inner wall, a consciously built structure. Rather, it might be seen as remains of a housing area, as was already mentioned by Nop et al. (1996) in their final thesis. The accumulation of settlement remains is evidenced by huge amounts of potsherds and stone tools. The entrance is located at the lowest part of the structure in the southwest, opposite the elevated zone. A 6- to 25-m-wide path leads from the inner plateau to the outer surface.

Upon observation of this cross section it becomes obvious that the ditches of the earthworks could not have been used for water storage. Their usage as moats can definitely be excluded since frequently the bottom of the trench on one side is higher than the top of the trench at the other because of the earthwork's location on a slight slope. The ditches are simply not able to hold water. A defensive purpose for these circular earthworks, as many authors proposed (e.g., Dega 1999; Groslier 1966a; Malleret 1959; Nop et al. 1996), is questionable as well. Structures with a wall slightly rising at the outside and falling steeply down to a shallow u-shaped inner ditch are counterproductive to defensive aims. The access into the 
structure seems much easier than the opposite way, even if the top of the rampart was armed by wooden palisades as Malleret (1959) argued. To discuss the function of this site group more profoundly, it is necessary to collect more detailed data on the location of the earthworks, their specific layout and material culture (Haidle and Thuy in prep.). The specific and very homogeneous layout of the circular earthworks in the red soil region of eastern Cambodia and southern Vietnam clearly distinguishes this site group from artificially or naturally moated sites in northeastern Thailand (Higham and Thosarat 1999; Moore 1988). The earthworks of Cambodia and Vietnam are nearly circular in shape with a diameter ranging between 200 and $260 \mathrm{~m}$ with few exceptions. The typical outer wall and inner ditch are consciously built structures that were constructed to enclose the prehistoric sites. In contrast, several of the sites from Thailand proved to be prehistoric occupations within lowland terrain on old river slings and swamp deposits. The "moats," however, were perhaps of natural origin or formed only recently (Higham and Thosarat 1998:147).

\section{The 1997 to 2000 Campaigns}

In the course of the last four campaigns, altogether 11 test trenches (Units I-VII and X-XIII) have been excavated (see Fig. 5). Their locations were chosen in order to collect as much information as possible about the structure and the function of the earthwork. The very homogeneous dark reddish brown soil (Munsell color charts $10 \mathrm{R} 3 / 3$ to $10 \mathrm{R} 3 / 2$ ) at the site is rather acidic with a $\mathrm{pH}$ value below 4.0, which makes long-term preservation of organic material such as bone, and even metal such as bronze and iron, impossible. Its uniformity does not allow the recognition of different layers by soil color; it is only possible to differentiate natural strata by slight changes in soil structures or occupational layers by artifact concentrations.

Unit I showed the inner structure of the earth rampart. About $2.5 \mathrm{~m}$ of the original construction was still preserved. The wall seems to have been built in one phase as few artifacts have been found and only in its lowest part.

Unit II is situated at the edge of the inner plateau, sectioning the so-called inner wall and the ditch. With $37 \mathrm{~m}^{2}$ excavated, Unit II gave the most interesting results. In the following discussion on artifact distribution patterns and important finds, we will concentrate on that area, mainly on the $9 \mathrm{~m}^{2}$ excavated in 1998 . The detailed analysis of the 2000 finds is still in progress, and only preliminary results can be presented here.

The $4 \mathrm{~m}^{2}$ of the trench extending into the ditch showed that the floor during the time of occupation was parallel to the modern surface profile. Only a few potsherds were recognized. The ditch was never used as a dump.

Another elevated zone that seemed to be an artificial mound (Unit III) was examined by digging a $4-\mathrm{m}^{2}$ trench. The artifact concentration, including potsherds, stone adzes, and stone flakes, was rather dense. Only one occupational layer was identified. The area is regarded as part of the settlement area at the edge of the inner plateau.

Unit IV, $14 \mathrm{~m}^{2}$, is situated near the entrance along the edge of the inner plateau in an almost nonelevated area. Again, only one occupational layer could be observed here. In contrast to the units in the elevated zone in the north and east of the inner plateau (Units II, III, X, XI, XII), few potsherds, but numerous 
stone adzes and flakes, were found. This area can be interpreted as a production place for stone tools and not a habitation zone.

In the center of the earthwork, $2 \mathrm{~m}^{2}$ (Units $\mathrm{V}$ and XIII) have been excavated. The distribution of the few findings in Unit $\mathrm{V}$ is an argument for a repeated occupation of the Krek Earthwork 52/62 as postulated by Nop et al. (1996). Potsherds occur in three levels: the first, at a depth of 50 to $75 \mathrm{~cm}$ below the surface; the second, between 90 and $100 \mathrm{~cm}$; and the last, at a depth of $100 \mathrm{~cm}$ below the surface. Repeated planting or ploughing could have disturbed the original position of the finds. Beside the sparsity of finds, which makes it difficult to clearly differentiate occupation layers in this unit, this possible repeated occupation of the earthwork could not be proven in the nearby Unit XIII excavated in 1999. Few potsherds and only one broken adze were found between 50 and $70 \mathrm{~cm}$ below the surface, in contrast to the wide vertical distribution of artifacts in Unit V.

To understand the situation at the entrance, we excavated two test pits in the area, Units VI and VII. Unit VI is located outside the outer wall in front of the entrance. Only a few potsherds were discovered between 80 and $90 \mathrm{~cm}$ below the surface. Unit VII is between the outer wall and the inner platform on the land bridge. Artifact distribution is even less dense than in Unit VI. Only 20 potsherds and 4 stone artifacts were scattered between 50 and $110 \mathrm{~cm}$ below the surface. The test pit also revealed that there was natural soil immediately underneath these rare artifacts. An entrance "bridge" through the ditch had not been constructed and no soil had been removed from that area (and no sediment had been piled at the dam section). The entrance was situated on the natural soil surface. It is clear that the zone close to the entrance was not a habitation area, but only a pathway. Four other units were excavated in the spring of 1999. To distinguish these test trenches from the previous examined locations, numbering starts with Unit X.

Unit $\mathrm{X}$ is located in the eastern portion of the site at the edge of the inner plateau. The finds were similar to other units at the same depth of the elevated area. A concentration of artifacts was found at a layer 50 to $60 \mathrm{~cm}$ below the surface, but in contrast to most other units, single finds could be observed from the surface to a depth of $120 \mathrm{~cm}$. There might have been a disturbance from a fallen tree.

Unit XI is situated to the northwest of the site, still on the elevated area at the edge of the inner plateau. The number of artifacts found was quite low. Concentrations of artifacts were found between 80 and $100 \mathrm{~cm}$ below the surface and suggest a single occupation layer. At $160 \mathrm{~cm}$ below the surface, single potsherds still occurred, a feature similar to Unit X.

Unit XII is also located in the elevated zone. A concentration of artifacts, mainly stone adzes and flakes, was found at a depth of between 60 and $80 \mathrm{~cm}$. Of interest is the vertical distribution of potsherds between 90 and $100 \mathrm{~cm}$ below the surface and $30 \mathrm{~cm}$ below the main distribution of finds. There we found two nearly complete jars together with some potsherds. Given the similarities with the situation in Unit II, square J/10 (see below), one explanation could be the existence of a burial pit underneath a single occupation layer.

\section{The Features in Unit II}

A more detailed look of Unit II, which was excavated in artificial layers of 10 to $15 \mathrm{~cm}$, yields more information on the different aspects of the activity zone at the 
edge of the inner plateau. The "inner wall" should obviously not be regarded as a constructed element of the structure but as the remains of an intensely occupied activity zone.

A total of $9.66 \mathrm{~m}^{3}$ of sediment, originating from the $9 \mathrm{~m}^{2}$ from Unit II excavated in 1998, was examined in detail (Table 2). This yielded 1,220 stone artifacts $(3.473 \mathrm{~kg})$ which, besides 846 flakes larger than $1 \mathrm{~cm}$, consist of 29 adzes and related stone tools, 6 polishing stones, 1 fragment of a stone bracelet, and 4 other stone artifacts. From the same area, 21,049 potsherds $(60.926 \mathrm{~kg})$ were collected, 1453 of which are larger than $4 \mathrm{~cm}$.

Regarding the density of potsherds (Fig. 7) and other findings, only one occupational layer can be identified. The zone of highest artifact concentration has a thickness of slightly more than $20 \mathrm{~cm}$; the maximum scattering of the finds amounts to more than $60 \mathrm{~cm}$.

In the southern section, a high density of artifacts occurs $30-40 \mathrm{~cm}$ deeper than in other parts of the site. A mapping of the archaeological horizon AH 6, the last one above sterile soil, clearly shows two pits, one in the southern square $\mathrm{J} / 10$ and another in $\mathrm{M} / 10$ and $\mathrm{N} / 10$ at a distance of $2 \mathrm{~m}$ (Fig. 8a).

The beginning of these pits can already be recognized in layer AH 5 (Fig. 8b). Considering the distribution in both lower horizons 5 and 6 , the pits perhaps stretched from the north-northwest to the south-southeast. Besides these distribution patterns there is no possibility of recognizing any structures because the soil is completely homogeneous. It shows no differences in color or structure that could enable us to identify even pits or postholes.

Another hint that these artifact concentrations might represent pits is the presence of a few nearly complete jars, which were gathered mainly in square $\mathrm{J} / 10$ in the lower layers. Three vessels in this square were nested into one another (Fig. 9); the upper part of the uppermost pedestaled bowl was cut by later activities.

With all circumspection needed because no bones have been preserved, these pits might eventually be interpreted as burial pits laid out after the occupation of that area. The postulated burial pits seem to have been artificially dug in the ground in a later phase or at the end of the main settlement activities-therefore the probable offering vessels have been almost completely preserved in their place of deposition. In addition to the vessels, a spindle whorl was found in square $\mathrm{J} / 10$ (Fig. 10), which could be an additional argument for this interpretation.

In each pit one complete polisher was excavated; other complete pieces were discovered in square $\mathrm{K} / 10$ and $\mathrm{N} / 10$. One from $\mathrm{K} / 10$ has never been used. Four complete adzes were found in the area of the northern pit but none in the southern: the remaining five complete adzes are concentrated in squares $\mathrm{K} / 9$ and $\mathrm{L} / 10$.

The distribution of the remains of more ordinary activities-flakes from adze production, broken adzes and polishers-is different. In a single square meter, between $\mathrm{L} / 10$ and $\mathrm{M} / 10,10$ adze fragments were discovered; the other 14 pieces show no concentrations. Considering that only one occupation seems to be documented at the site, the density of adzes and their fragments is extremely high. Four of the nine broken polishers are concentrated in the center of square $\mathrm{K} / 9$, close to the concentration of adze production flakes in $\mathrm{L} / 9$. Besides this higher density in the southeastern quarter of square L/9 the flakes do not show any specific distribution. They are scattered over the area. 
Table 2. Distribution of Potsherds and Stone Tools at Krek 52/62

\begin{tabular}{|c|c|c|c|c|c|c|c|c|c|c|c|}
\hline \multirow[b]{2}{*}{ UNIT } & \multirow[b]{2}{*}{$\mathrm{m}^{3}$} & \multicolumn{5}{|c|}{ POTSHERDS } & \multicolumn{5}{|c|}{ STONE TOOLS } \\
\hline & & $\begin{array}{c}\text { NO. OF } \\
\text { PCS }\end{array}$ & $\begin{array}{l}\text { WEIGHT } \\
(\mathrm{g})\end{array}$ & $\mathrm{G} / \mathrm{PC}$ & $\operatorname{PCS} / \mathrm{M}^{3}$ & $\begin{array}{l}\text { WEIGHT } \\
(\mathrm{g}) / \mathrm{m}^{3}\end{array}$ & $\begin{array}{c}\text { NO. OF } \\
\text { PCS }\end{array}$ & $\begin{array}{l}\text { WEIGHT } \\
\text { (g) }\end{array}$ & $\mathrm{G} / \mathrm{PC}$ & $\mathrm{PCS} / \mathrm{M}^{3}$ & $\begin{array}{l}\text { WEIGHT } \\
(\mathrm{g}) / \mathrm{m}^{3}\end{array}$ \\
\hline I & 6.00 & 88 & 369 & 4.19 & 15 & 62 & 7 & 61 & 8.71 & 1 & 10 \\
\hline II, 1997 & 1.40 & 252 & 2621 & 10.40 & 180 & 1872 & 32 & 468 & 14.63 & 23 & 334 \\
\hline II, 1998 & 9.66 & 21049 & 60926 & 2.89 & 2179 & 6307 & 1220 & 3473 & 2.85 & 126 & 360 \\
\hline II, ditch & 6.12 & 124 & 191 & 1.54 & 20 & 31 & 13 & 64 & 4.92 & 2 & 10 \\
\hline III & 2.24 & 192 & 1428 & 7.44 & 86 & 638 & 36 & 570 & 15.83 & 16 & 254 \\
\hline IV & 5.99 & 2538 & 5238 & 2.06 & 424 & 874 & 281 & 1113 & 3.96 & 47 & 186 \\
\hline V & 1.26 & 122 & 345 & 2.83 & 97 & 274 & 0 & 0 & 0 & 0 & 0 \\
\hline VI & 0.94 & 30 & 67 & 2.23 & 32 & 71 & 0 & 0 & 0 & 0 & 0 \\
\hline VII & 0.83 & 20 & 98 & 4.90 & 24 & 118 & 4 & 148 & 37.00 & 5 & 178 \\
\hline $\mathrm{X}$ & 1.30 & 1125 & 3611 & 3.21 & 865 & 2778 & 126 & 405 & 3.21 & 97 & 312 \\
\hline XI & 1.70 & 348 & 1436 & 4.13 & 205 & 845 & 19 & 252 & 13.26 & 11 & 148 \\
\hline XII & 1.31 & 601 & 2393 & 3.98 & 459 & 1827 & 74 & 358 & 4.84 & 56 & 273 \\
\hline XIII & 1.20 & 8 & 45 & 5.63 & 7 & 38 & 1 & 27 & 27.00 & 1 & 23 \\
\hline Total & 39.95 & 26497 & 78768 & 2.97 & 663 & 1973 & 1813 & 6939 & 3.83 & 45 & 174 \\
\hline
\end{tabular}




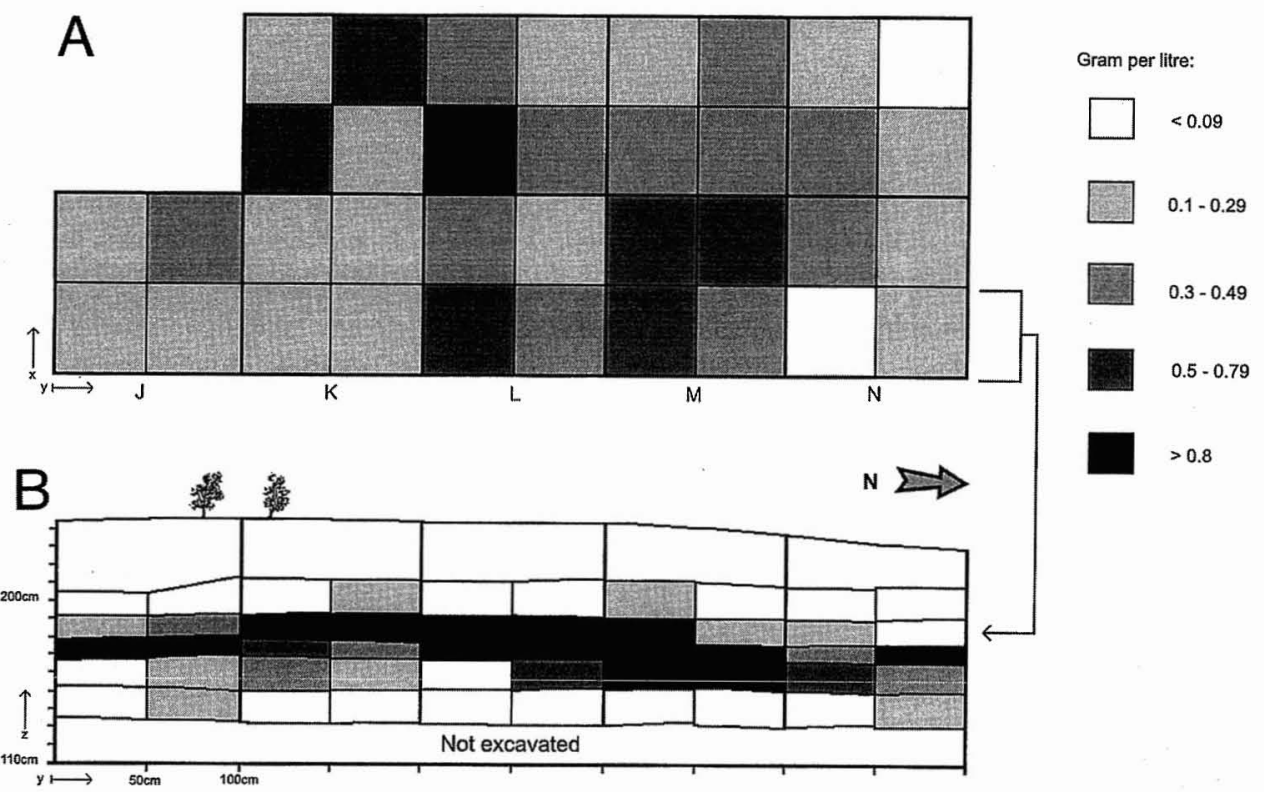

Fig. 7. Vertical density of potsherds in south-north profile, Krek 52/62, Unit II, 1998. A: stone tools all levels; B: stone stools in north-south profile.

\section{The Finds}

The different types of stone artifacts present at the site indicate a complete sequence of stone tool production, repeated use, retooling, and discard. The preferred raw material for flaking and the production of adzes was amphibole-hornfels type metamorphic rock (Neumann 1999). The original state and hardness can be observed only on fresh breakage. The surface of the flakes and adzes has been heavily altered by acidic soil conditions, the weathered portion changing to light gray, beige, or sand colored. It is very soft and can easily be scratched and incised with fingernails, but originally the raw material seems to have had fairly good properties: it allowed the flaking of thin blades and fine retouch.

Much of the debris offers evidence that adze production occurred at the site. Roughly flaked adze blanks, which were discarded before polishing, were found, as well as finely polished adzes, adzes with use scars, and adze fragments. Numerous polishers and whetstones, mainly made of sandstone, were discovered. In most cases these tools display several working surfaces. One of the whetstones (Fig. 11) with narrow grooves cut into the sandstone was most probably used to sharpen edges of cutting tools that might have been made of metal.

Two main types of adzes have been observed: thin-butted adzes and shouldered ones. The size of both types varies markedly. The maximum width of a cutting edge is $10 \mathrm{~cm}$, the minimum is $1.5 \mathrm{~cm}$. The use-wear at the cutting edges indicates the use of these small adzes for very fine wood working at the site. Besides the adzes, a few ground and polished pointed objects were found at the site produced from the same metamorphic rock raw material. 


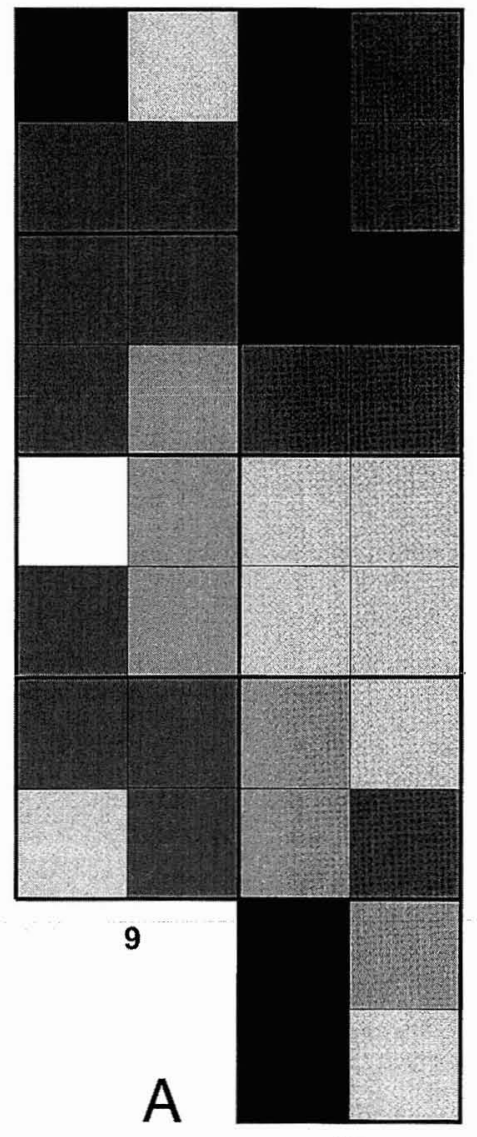

10

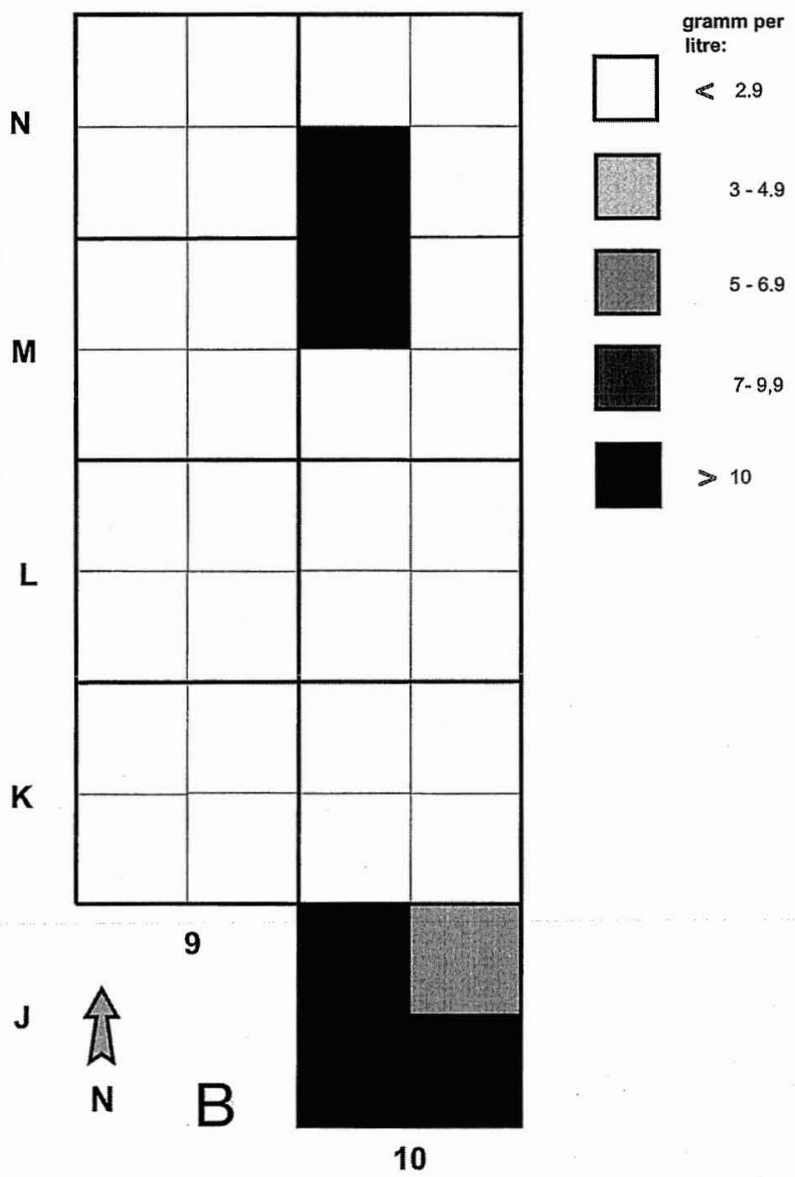

Fig. 8. Horizontal density of potsherds in Krek 52/62, Unit II. A: level AH 5; B: level AH 6.

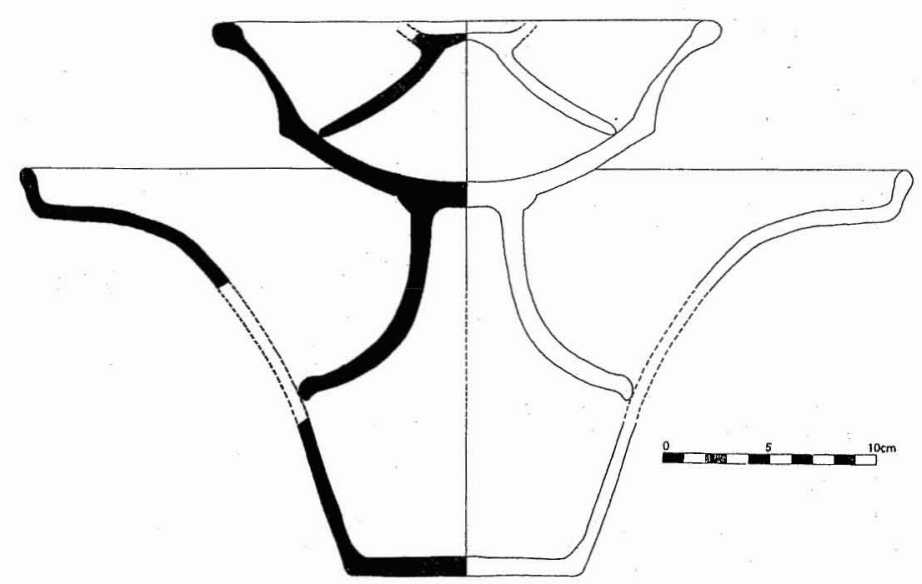

Fig. 9. Three nested vessels from Krek 52/62, Unit II, square J/10. 


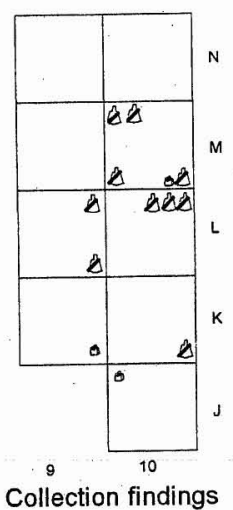

Potsherd

- Adze

2. Adze, fragment

- Stone flake

- Polisher

- Polisher, fragment

$\star 1$ Spindle whorl

$\star 2$ Stone bracelet

$\star 3$ Glass bracelet

\section{KREK $62 / 52$}

Area II, 1998, all levels

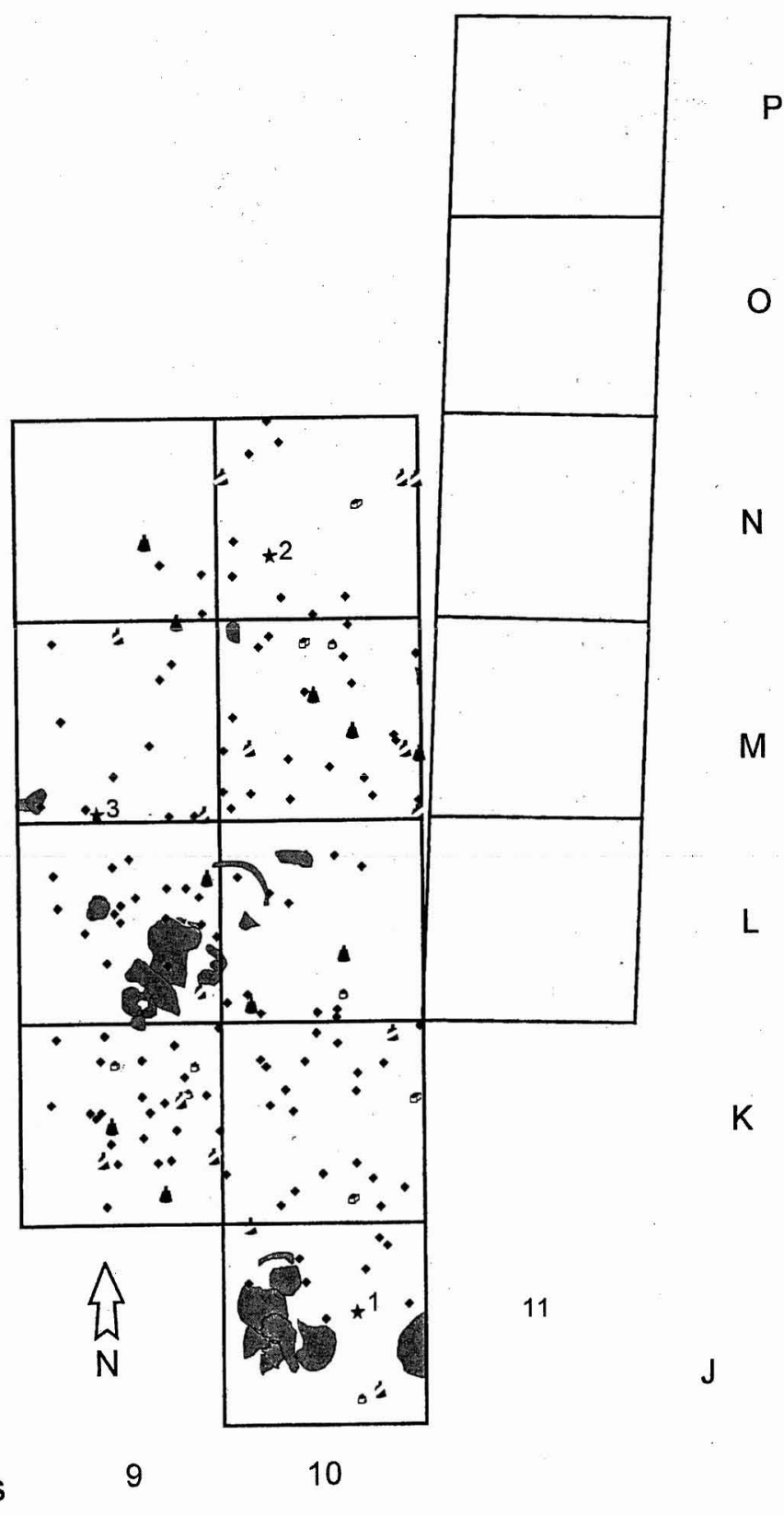

Fig. 10. Horizontal distribution of artifacts in all levels, Krek 52, Unit II.

In spite of the common interpretation of the sites as Neolithic fortifications, only three pointed artifacts were found in Krek 52/62, only one of which could be categorized as an arrowhead. Another type of artifact that is likely to have been produced in or nearby the earthwork is pottery. A conical anvil made of ceramic with mineral temper is evidence that a "paddle and anvil" technique was 

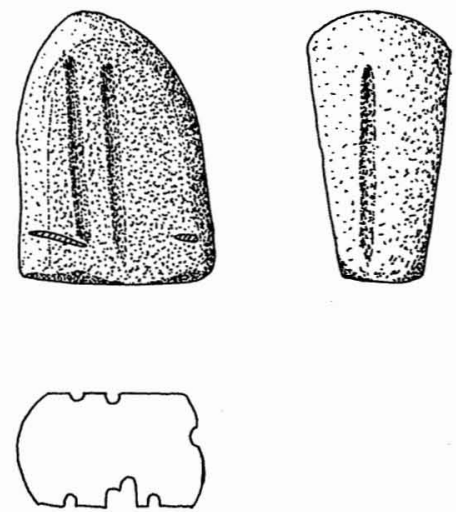

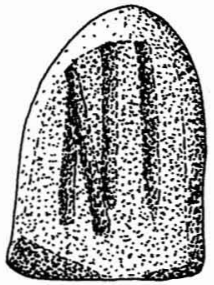

Fig. 11. Whetstone made from sandstone with three working surfaces (Krek 52/62, Unit II).
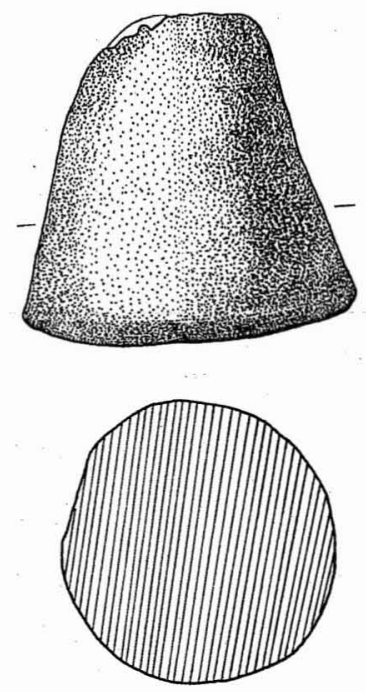

Fig. 12. Ceramic anvil used in pottery production (Krek 52/62, Unit II).

used (Fig. 12). The very thin-walled ware (2 to $8 \mathrm{~mm}$ thickness of the wall) fits well with this assumption. Mineral as well as organic temper material was used: Barbara Albrecht identified charred remains of rice husks and even impressions of rice grains $(\mathrm{Pl}$. I).

The pottery was burned under reducing and oxidizing conditions with low temperatures as in an open fire. The color of the ware ranged from beige to red and from gray to nearly black. Some vessels still show remains of a slip, but the surfaces of potsherds are greatly damaged due to the acidic soil and weathering conditions. Various motifs of incised, indented, and impressed (cord-marked) decoration are documented (Fig. 13).

A variety of vessel shapes and rim forms were in use at the site. Clearly to distinguish from the everyday ware-bowls, cooking pots, and small storage vessels - are huge jars connected with the supposed burial pits. One example, a nearly complete footed, sharply shouldered bowl from square $\mathrm{J} / 10$ (Fig. 14), gives an indication of the high quality of some of the pottery from Krek 52/62. 


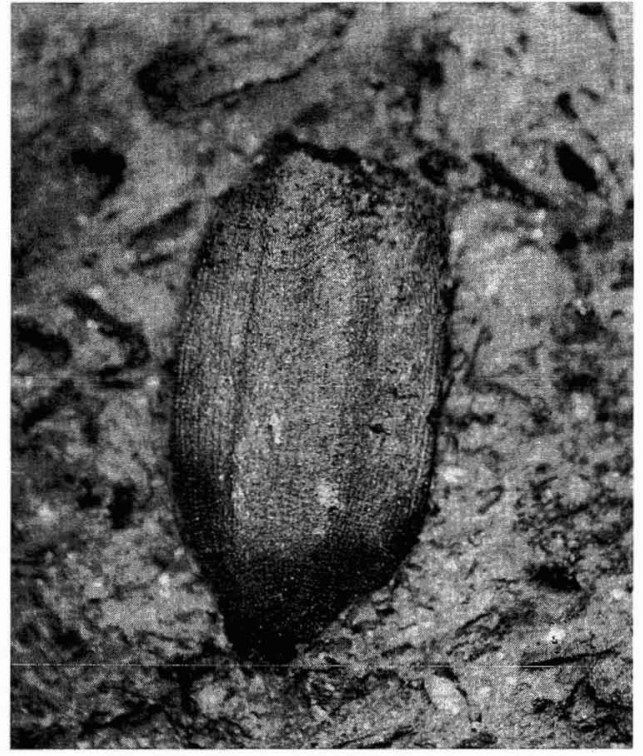

Pl. I. Organic temper from Krek 52/62 pottery: fragments of rice husks and the impression of a rice grain.

Additionally, a small conical spindle whorl (Fig. 15) made of ceramic, $2.3 \mathrm{~cm}$ high and with an original maximum diameter of $3.5 \mathrm{~cm}$, was found in $\mathrm{J} / 10$. Its decoration is composed of four indented spirals. In 2000 the fragment of another, yet undecorated ceramic spindle whorl with flat semicircular cross section was discovered in square $\mathrm{J} / 9$. Its maximum diameter is $2.8 \mathrm{~cm}$ with a height of $1.2 \mathrm{~cm}$. These finds might indicate the possible processing of fibers and the production of fabrics at the site.

An unprepossessing but important artifact might be associated with the probable pit in square $N / 10$. The heavily weathered fragment belonged to a finely worked bracelet made of metamorphic raw material, the same material from which the flakes and adzes were made. The nearly rectangular cross section of the fragment is $5 \mathrm{~mm}$ high and $4 \mathrm{~mm}$ wide. The inner diameter of the bracelet was reconstructed to $5.8 \mathrm{~cm}$. No decorative patterns can be observed at the surface of the gray ornament. Parallels to this piece are present in the artifact sample from Groslier's excavation stored at the National Museum, Phnom Penh (Thuy 1999).

In 2000, another stone ornament was discovered in the upper parts of the cultural layer in Unit II, square J/9. The natural form of the garnet stone with a nearly triangular cross section was maintained: it was simply perforated with double-conical drilling. The measurements of the bead are $10.9 \mathrm{~mm}$ in length, $10.9 \mathrm{~mm}$ in width, and $8.5 \mathrm{~mm}$ in height. Today, garnet is known to accompany ruby and sapphire deposits; the closest to our sites are situated in Rattanakiri province, northeast Cambodia (Udo Neumann, pers. comm.).

The most extraordinary discoveries were made in 1998 in square M/9 (Fig. 16) and in 2000 in L/8 (Haidle 2002). Two fragments of two glass bracelets were found in situ in the upper part of the squares, but well within the normal artifact distribution. The discovery of the second glass bangle makes any secondary, more recent intrusion quite unlikely. All other finds at the site, pottery and stone tools, 


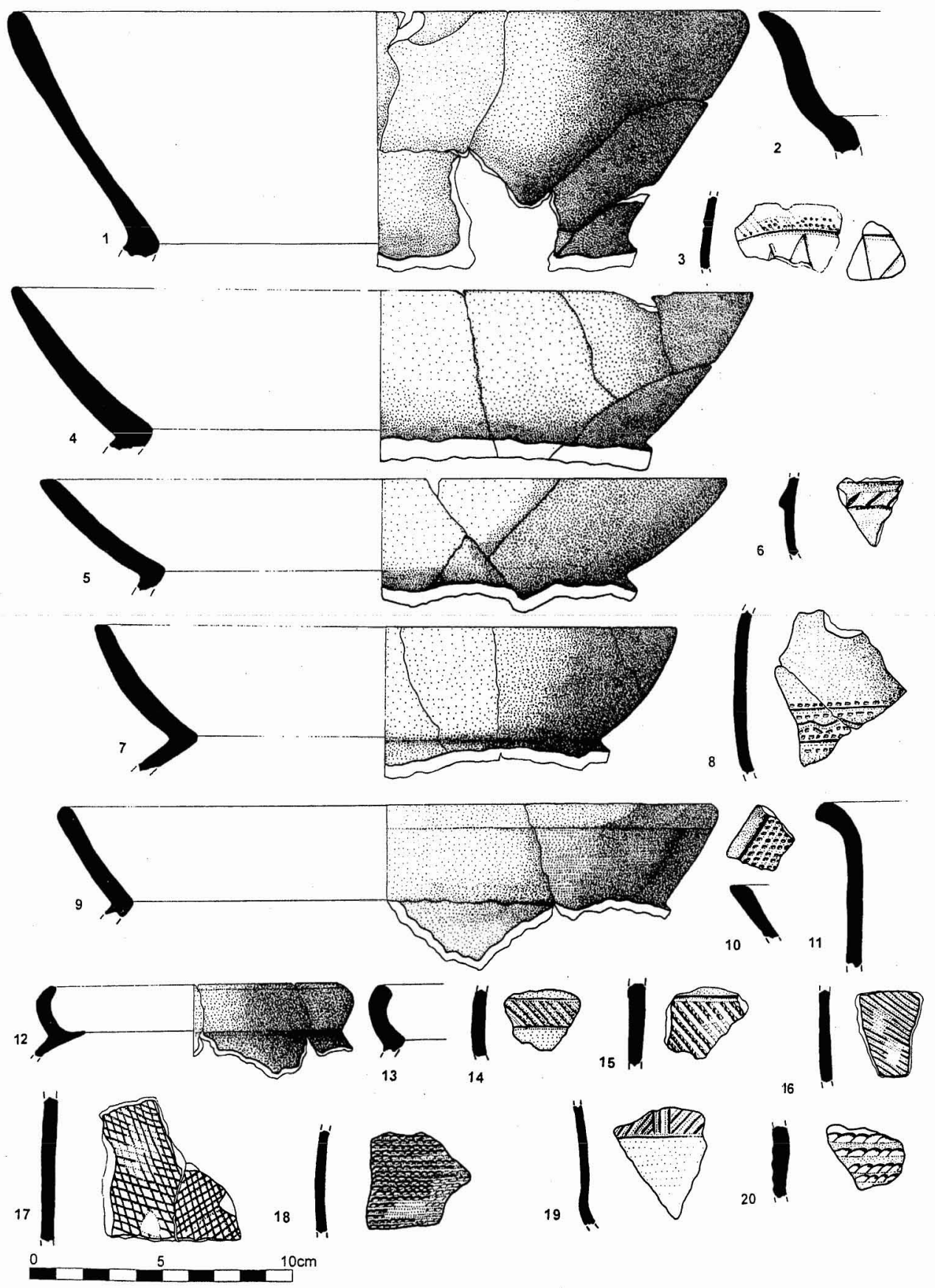

Fig. 13. 1-20: examples of pottery form and decoration types from Krek 52/62. 


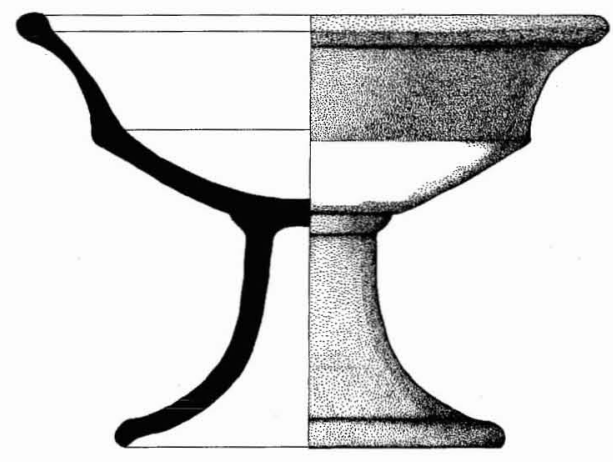

Fig. 14. Footed, sharply shouldered bowl from Krek 52/62, Unit II, square J/10.
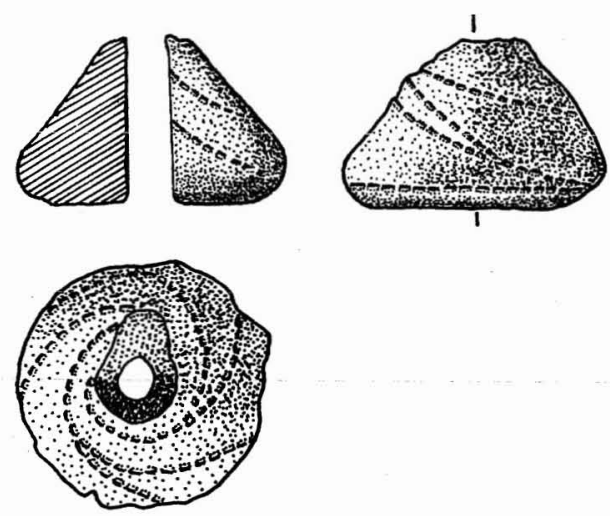

Fig. 15. Ceramic spindle whorl (Krek 52/62, Unit II, square J/10).

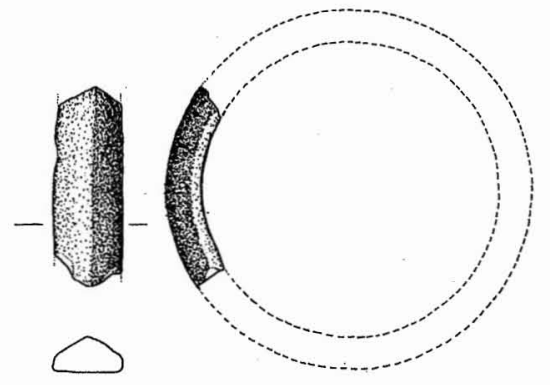

Fig. 16. Fragment of a bracelet of dark green translucent glass with house-shaped cross section (Krek $52 / 62$, Unit II, square $M / 9)$.

form a very homogeneous sample. The cross section of the fragments made from dark green and light green translucent glass resembles a flat house with slightly rounded edges; $\mathrm{M} / 9-13$ is $6.5 \mathrm{~mm}$ high and $13 \mathrm{~mm}$ wide, $\mathrm{L} / 8-12$ is $6.8 \mathrm{~mm}$ high and $12.8 \mathrm{~mm}$ wide. The reconstructed inner diameter of $\mathrm{M} / 9-13$ measures $5.8 \mathrm{~cm}$ as does one of the stone bracelets. Comparable pieces were found in Do Trang Suc Bang Thiec in southern Vietnam (exhibited in the Museum of Vietnamese History, Ho Chi Minh City) and in Ban Don Ta Phet, Kanchanaburi province, Thailand (Glover and Henderson 1995:148). The chemical analyses of the fragments point to an Indian origin of the glass masses (Haidle 2002). 


\section{Dating}

The circular earthworks in the red soil region of eastern Cambodia and adjacent Vietnam have frequently been mentioned as Neolithic in age because of surface finds (Carbonnel 1979; Dega 1999; Groslier 1966a; Kojo and Pheng 1997; Malleret 1959; Manh 1996). Luong Ninh (1985, cited in Do 1999), however, determined the site group as being late Bronze to early Iron Age in origin within the second to first millennium B.C. Correspondingly, Ngyuen Trung Do estimates an age of 3500 to 2500 в.P. based on comparative studies of artifact samples from other prehistoric sites in Nambo (Do 1984, 1987, cited in Do 1999). Nguyen Van Long (1986, cited in Do 1999) dated the circular sites even later to 2500 to 2000 B.P. Until recently, no radiometric dating was done due to the problem of the almost complete absence of organic material at the sites. As a result of the aggressive chemistry of the red soils only pottery and stone artifacts have been preserved. This fact might lead to the conclusion that this site type is of Neolithic origin. But is it not possible that this conclusion is an artifact of the soil chemistry? Not only bone and other organic material are affected by the very acidic composition of the soil but also iron and even bronze.

The fragments of glass bracelets provide a clue that these circular earthworks might be much younger than believed (Haidle 2002). A parallel to these artifacts from Thailand is well dated to the Iron Age of the fourth century B.C. (Glover and Henderson $1995: 148$ ).

The stone artifacts of the circular earthworks are not specific to one chronological phase; similar adzes have also been found in Metal Age contexts. At least partly, the pottery is very elaborate in technology and shape and might fit as well in Bronze or even Iron Age samples. According to the finds, a first millennium B.C. date is probable: although metal tools are not preserved, the discovery of lumps of iron ore in some sections of Krek 52/62 might indicate iron processing by the prehistoric settlers.

The discovery of lithophones in several circular earthwork sites may become an additional argument for a revised dating of the circular earthworks. One such fragment was discovered among the old collection of B. P. Groslier in the National Museum, Phnom Penh (P1. II) (Thuy 1999).

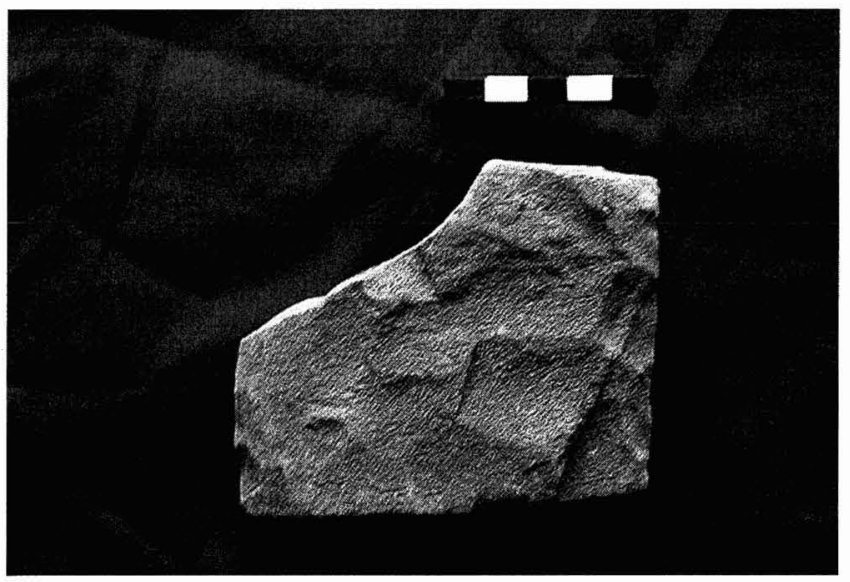

P1. II. Fragment of a lithophone from the Groslier site. Collection of B. P. Groslier, National Museum, Phnom Penh. 
Table 3. Radiocarbon Dates on Organic Temper from Krek 52/62 Pottery

\begin{tabular}{lccc}
\hline LAB. NO. & NAME & ${ }^{14}$ C B.P. & CALibrated AGE \\
\hline ETH-18972 & Sample 1 & $3495 \pm 75$ & $1920-1690$ B.C. \\
ETH-18975 & Sample 2 & $3990 \pm 70$ & $2620-2350$ B.C. \\
\hline
\end{tabular}

More fragments were found by the authors in March 1999 during a visit at a circular earthwork site in Phu Mieng, Binh Long district, South Vietnam (Malleret site No. 8). Shortly before our visit, farmers (?) had dug a huge trench into the elevated area at the edge of the inner plateau in the southwestern section of the site. The remains of two lithophones were left near the trench together with large grinding stones and other unworked stones. The fragments of the lithophones were immediately handed over to the Vietnamese authorities in Ho Chi Minh City (cf. Manh 1999). Additional evidence of lithophones from circular earthworks is reported by Manh (1999) for the sites of Loc Hoa and Loc Thang. Even taking that the dating of lithophones is still open to discussion (Manh 1996), it is important to note that this is the first time that lithophones have clearly been connected with the "Mimotien" archaeological complex.

A first attempt to obtain radiocarbon dates was made on a piece of charcoal buried under a large potsherd in Unit II of Krek 52/62. The singular accelerator date of $293 \pm 70$ B.P. (Wk-5692, $\delta{ }^{14} \mathrm{C}-44.9 \pm 8.3 \%$, $\Delta{ }^{14} \mathrm{C}-41.3 \pm 8.4 \%$, $\delta^{13} \mathrm{C}-26.8 \%$ ) is much younger than expected. As we know today, there is no chance of organic material being preserved since the time of the occupation due to the acidity of the soil unless the remains are covered by inorganic material, e.g., organic temper of potsherds. Most probably the piece of charcoal tested was a charred root of a recent plant or tree and is not related to the archaeological context. Potentially optimal organic material of close context to the site is rice husk pottery temper. The rice husks have been preserved as traces even after the firing of the pottery. Samples of potsherds that showed clear traces of rice husks under the microscope were submitted to the AMS ${ }^{14} \mathrm{C}$ Laboratory of Zurich, Switzerland. In a first run, two preliminary results were obtained (Georges Bonani, pers. comm.) (Table 3). We were warned, however, that the samples contained only a small amount of carbon, and therefore, the ${ }^{14} \mathrm{C}$ dating must be treated with caution, as contamination of the clay, by older carbonaceous material, cannot be ruled out. In fact, this may explain the ${ }^{14} \mathrm{C}$-age difference of the two samples that are considered contemporaneous. Sample processing to avoid these mistakes are being developed at the Zurich and Heidelberg ${ }^{14} \mathrm{C}$ laboratories. Only recently, Michael Dega et al. (2000) presented five new radiocarbon dates based on the organic temper of pottery from four earthworks. The dates range from 2290-2030 в.c. (95.4 percent) from the deepest part of the occupational layer at Trameng earthwork near Memot to 400-350 B.C. (44.0 percent) or 320-200 B.C. (51.4 percent), respectively, from the top of the occupational layer at Chi Peang earthwork near Krek. The date of the occupational terminus at Chi Peang would indicate an Iron Age end of the Mimotien complex as do the glass bangles from Krek 52/62. However, the samples dated by Dega face the same problems of contamination as the samples from Krek 52/62 and should be evaluated critically. 


\section{CONCLUSIONS}

The excavated areas are by far too small for any fundamental interpretation and it is useless to stress the data too much. But there are some remarkable clues regarding the activities at Krek 52/62 that enable us to draw a clearer picture of the structural and functional use of the circular earthworks of the red soil region. Regularly, the sites consist of an outer rampart with a flat outer and a steep inner embankment and a shallow inner ditch. The so-called inner wall that was documented for the sites proved to be, at least for Krek 52/62, Phoum Kampoan, and Phoum Beng, the remains of an intensely occupied activity zone and not a consciously constructed structural element. This zone can be interpreted as the main settlement area. The center of the structure was used for a different purpose. Typically, the circular structures have one or two entrances that occur in a simple form as at Krek 52/62, Phoum Beng, Chamkar.Thmey, and Phoum Chong, or as complex constructions as at Phoum Kampoan, Huon Khim, Groslier site, Chhok Khley, Loc Ninh, and Phu Mieng.

The artifact assemblage evidences the production of pottery and stone tools at Krek 52/62. Numerous adzes and two spindle whorls found at the site are indirect evidence for wood working and the processing of fibers. The rice husks and grains used as pottery temper indicate agricultural subsistence patterns. Pointed artifacts are very rare in Krek 52/62 and are missing in the samples from the other earthworks investigated so far. No other weapon-like artifacts were found.

Looking at the results from Krek 52/62, the Neolithic dating of the site group has to be questioned. The evidence from two fragments of two glass bracelets are arguments for a date at least at the end of the Mimotien complex to the second half of the first millennium B.C. The lack of metal objects could be due to the aggressive chemistry of the red soils. Considering the evidence from the excavations at Krek 52/62, Phoum Beng, and Phoum Kampoan, as well as from surveys at other sites, the common interpretation of the circular earthworks of Cambodia and Vietnam as Neolithic fortifications becomes unlikely. The sites belong to a former system of homogeneously constructed rice-farming villages. These are commonly situated on topographically dominant spots in the red soil area of east Cambodia and adjacent Vietnam in an area stretching $100 \mathrm{~km}$ east-west and 30$40 \mathrm{~km}$ north-south. The circular earthworks of Cambodia and Vietnam seem to be the archaeological remains of an economical, social, cultural, and therefore even political entity in the first millennium B.C. These promising results should encourage fieldwork to continue and archaeologists to intensify their prehistoric research in Cambodia.

\section{REFERENCES}

Albrecht, Gerd, and Miriam Noël Haidle

1999 Im Schatten von Angkor Vat? Archäologie in Deutschland 3/1999, 14-19.

Carbonnel, JeAn-Pierre

1970 Le Quaternaire Cambodgien. Structure et Stratigraphie. Unpublished thesis, Paris.

1979 Recent data on the Cambodian Neolithic: The problem of cultural continuity in Southern Indochina, in Early South East Asia: 223-226, ed. R. B. Smith and W. Watson. Oxford: Oxford University Press. 
Carbonnel, Jean-Pierre, and Georgette Delibrias

1968 Premières datations absolues de trois gisements néolithiques Cambodgiennes. Comptes Rendus de l'Académie des Sciences de Paris, t. 267, série D: 1432-1434.

ChHor, Sivleng, Kada Sirik, AND Thol UN

1999 Beng Circular Earthworks. Unpublished thesis, Faculty of Archaeology, RUFA, Phnom Penh, Cambodia.

Dega, Michael F.

1999 Circular settlements within Eastern Cambodia. Bulletin of the Indo-Pacific Prehistory Association 18:181-190.

Dega, Michael F., Vet Kou, Chamroeun Chhan, and Sameh Koum

1997 Circular Earthworks in Kampong Cham: 1996 Archaeological Research. Bulletin de Liaison des Recherches au Cambodge 3, École Française d'Extrême Orient. 13-16. Phnom Penh.

Dega, Michael F., L. Poch, U. Moninitha, and C. Samouen

2000 The timing of Cambodian earthworks. Paper presented in the symposium "Recent Advances in Southeast Asian Archaeology" at the $65^{\text {th }}$ Society for American Archaeology meetings, Philadelphia, Pennsylvania.

Do, Nguyen Trung

1999 Circular earthworks in Binphuoc province. Paper presented at the Conference on Circular Earthworks in Cambodia, 14-19 November 1999, Phnom Penh.

Glover, IAN, AND Julian Henderson

1995 Early glass in South and Southeast Asia and China, in Southeast Asia and China: Art, Interaction and Commerce: 141-170, ed. R. Scott and J. Guy. Colloquies on Art and Archaeology in Asia 17. London: Percival David Foundation of Chinese Art.

Groslier, Bernard Phillippe

1966a Archaeologia Mundi: Indochine. Geneva: Nagel.

$1966 b$ Découvertes archéologiques récentes au Cambodge. Kambuja 16:76-81. Phnom Penh.

Haidle, Miriam NoËL

2002 Fragments of glass bangles from Krek 52/62 and their implications for the dating of the Mimotien culture. Asian Perspectives, in press.

Haidle, Miriam Noël, and Chanthourn Thuy

in prep Fortresses? Ceremonial Centres? Villages? Circular Earthworks in Eastern Cambodia. Proceedings of the $8^{\text {th }}$ Conference of the European Association of South East Asian Archaeologists, Sarteano, Italy, 2-6 October 2000.

Heang, Leang Hong

1999 The pottery from the Groslier circular earthworks site, stored in the National Museum Phnom Penh. Unpublished thesis, Faculty of Archaeology, RUFA, Phnom Penh, Cambodia.

Heng, Sophady, and Sophal Som

1999 Analysis of pottery from circular earthworks Krek 52/62. Unpublished thesis, Faculty of Archaeology, RUFA, Phnom Penh, Cambodia.

Heng, Than, and Someaphivath Mao

1999 Study of stone tools from circular earthworks 52/62. Unpublished thesis, Faculty of Archaeology, RUFA, Phnom Penh, Cambodia.

Higham, Charles F. W., and Rachanie Thosarat

1998 Prehistoric Thailand. From Early Settlement to Sukhotai. Bangkok: River Books.

1999 The circular sites of the Upper Mun Valley, Thailand. Paper presented at the Conference on Circular Earthworks in Cambodia, 14-19 November 1999, Phnom Penh.

Kojo, Yasushi, and Sytha Pheng

1997 A newly discovered earthwork in Southeastern Cambodia. Anthropological Science 105(3) : 181-187.

1998 A preliminary investigation of a circular earthwork at Krek, Southeastern Cambodia. Anthropological Science 106(3): 229-244.

LeVy, Paul

1943 Recherches Préhistoriques dans la Région de Mlu Prei Accompanées de Comparaisons Archéologiques et Suivies d'un Vocabulaire Français-Kuy. Hanoi: Publications de 1'EFEO, vol. 30. 
MALleret, Louis

1959 Ouvrages circulaires en terre dans l'Indochine Méridionale. Bulletin de l'École Française de l'Extrême Orient 49:409-434.

Manh, Pham Duc

1996 Proto-history and pre-history of the Eastern part of Nam Bo-past and modern perceptions. Vietnamese Studies 1996/2, Special: Archaeological Data II, New Series 50(120): 63-119.

1999 The prehistoric lithophone at Loc Ninh (Binh Phuoc-Vietnam). Paper presented at the Conference on Circular Earthworks in Cambodia, 14-19 November 1999, Phnom Penh.

Mansuy, HenRI

1902 Stations Préhistoriques de Somrong-Sen et de Long Prao (Cambodge). Hanoi: F. H. Schneider.

1923 Contribution à l'étude de la préhistoire de l'Indochine, III. Résultats de nouvelles recherches effectuées dans le gisement préhistorique de Somrong Sen (Cambodge). Suivi d'un résumé de l'état de nos connaissances sur la préhistoire et sur l'ethnologie des races anciennes dans l'Extrême Orient méridional. Hanoi: Mémoires du Service Géologique de l'Indochine 10.

Moore, Elisabeth

1988 Moated sites in Early North East Thailand. BAR International Series 400. Oxford.

Mourer, Cécile, and Roland Mourer

1970 The prehistoric industry of Laang Spean, Province of Battambang, Cambodia. Archaeology and Physical Anthropology in Oceania 5/2:128-146.

1971 Prehistoric research in Cambodia during the last ten years. Asian Perspectives 14:35-42.

Mourer, Roland

1977 Laang Spean and the prehistory of Cambodia. Modern Quaternary Research in Southeast Asia 3:29-56. Rotterdam.

1994 Contribution a l'étude de la préhistoire du Cambodge, in Recherches nouvelles sur le Cambodge: 143-195, ed. F. Bizot. Paris: École Française de 'Extrême-Orient.

Neumann, Udo

1999 Raw material of the stone artefacts from circular earthworks in Kampong Cham province, Cambodia and in S. Vietnam. Paper presented at the Conference on Circular Earthworks in Cambodia, 14-19 November 1999, Phnom Penh.

Nop, Rithea, Srong Oun, Kolthida Loeun, Phat Hoeung, and Sothunnindr Nup

1996 An archaeological study of a circular earthwork at Krek, Southeastern Cambodia. Unpublished thesis, Faculty of Archaeology, RUFA, Phnom Penh, Cambodia.

Noulet, Jean-Baptiste

1879 L'Áge de la Pierre Polie et du Bronze au Cambodge d'après les Découvertes de M. J. Moura. Toulouse: Archives du Musée d'Histoire Naturelle de Toulouse 1.

Pavie, Auguste

1904 Mission Pavie Indo-Chine 1879-1895. Étude diverses, vol. 3: Recherches sur l'histoire naturelle de l'Indo-Chine orientale par Auguste Pavie, Anthropologie: 1-40. Paris: Leroux.

SAURIN, EDMOND

1969 Les recherches préhistoriques au Cambodge, Laos et Vietnam (1877-1966). Asian Perspectives $12: 27-40$.

Sok, Kimsan, and Laychour Vin

1999 Stratigraphy and settlement patterns of circular earthworks Krek 52/62. Unpublished thesis, Faculty of Archaeology, RUFA, Phnom Penh, Cambodia.

Thuy, Chanthourn

1999 Groslier circular earthworks site in Memot District: The stone tools in the National Museum, Phnom Penh. Unpublished thesis, Faculty of Archaeology, RUFA, Phnom Penh, Cambodia.

\section{ABSTRACT}

Since 1996 research on circular earthworks in the red soil region of eastern Cambodia and adjacent Vietnam has intensified. Several as yet undocumented Mimotien sites have broadened the knowledge about the regional distribution, location, and 
the layout of this site group. Within the scope of a German teaching program at the Royal University of Fine Arts, Phnom Penh, intensive fieldwork at Krek 52/62 and soundings at Phoum Beng, Phoum Kampoan, and the Groslier site yielded more detailed information on the function and the dating of circular earthworks. Typically, the structures are situated on the top of a slight slope and are composed of an outer wall, an inner trench, and an inner central platform lower than the surrounding surface. The rampart could not be used as a water storage system. The elevation at the edge of the inner plateau can no longer be interpreted as intentional construction, but now is explained as the accumulation of an occupational layer. The circular earthworks possess one or two entrances that are constructed either as simple pathways or as complicated bridged systems. Both the profile of the sites (a steep inner side of the outer wall and a shallow inner ditch) and the absence of artifacts usable as weapons argue against the former interpretation as fortifications. Rather, the artifact assemblages of the sites supply evidence for villages of rice farmers. Fragments of lithophones belong to the archaeological assemblages of two circular earthworks. The dating of the sites to the Neolithic is questioned. First attempts of radiocarbon dating of the organic temper of the pottery did not yield clear results. However, a glass bracelet fragment found in situ well within the occupational layer of Krek 52/62 gives evidence for the first millennium B.C. date. KeYwords: Cambodia, red soil region, circular earthworks, Mimotien, early glass, lithophones. 